Relations industrielles

Industrial Relations

\title{
Statistics and Information
}

Volume 5, numéro 8, mai 1950

URI : https://id.erudit.org/iderudit/1023387ar

DOI : https://doi.org/10.7202/1023387ar

Aller au sommaire du numéro

\section{Éditeur(s)}

Département des relations industrielles de l'Université Laval

\section{ISSN}

0034-379X (imprimé)

1703-8138 (numérique)

Découvrir la revue

Citer ce document

(1950). Statistics and Information. Relations industrielles / Industrial Relations, 5(8), 79-80. https://doi.org/10.7202/1023387ar

Tous droits réservés @ Département des relations industrielles de l’Université Laval, 1950
Ce document est protégé par la loi sur le droit d'auteur. L’utilisation des services d'Érudit (y compris la reproduction) est assujettie à sa politique d'utilisation que vous pouvez consulter en ligne.

https://apropos.erudit.org/fr/usagers/politique-dutilisation/ 


\section{AWARDS BETWEEN APRIL 1 AND APRIL 30, 1950}

\section{J.J. Joubert Ltée vs Union Ouvrière des Employés de Lai- teries, Loval 973 (TLC).}

1. Working hours; 2. Ten days of paid holidays; 3. Vacations; 4. Pension funds; 5. Free coffee; 6. Reclassifcation of the employees; 7 . Withholding of union dues; 8. $15 \%$ general wage increase. Unanimous award, April 5, 1950. Justice Poisson. (*)

Thrift Stores Ltd. vs Retail Clerks' International Ass'n, Local 486 (TLC-AFL).

1. Upholding of affiliation; 2. Authorized absence for union duties; 3. Work week; 4. Overtime; 5. Vacations; 6. Wages; 7. Duration of contract and date of entrance into effect; 9. Warehouse employees. Unanimous award, April 5, 1950. Justice C.E. Guérin.

Canadian Allis Chalmers Co. vs United Electrical, Radio \& Machine Workers of America, Local 518 (CGL-CIO). All the clauses of the agreement. Employer and union dissident, April 6, 1950. Me Ulric Laurencelle. (*)

Retail Merchants Association of Canada, Inc., Furniture and Electrical Accessories, Novelties, and Shoe Sections, and the Quebec Employers' Trade Association vs Syndicat cath. des Employés de magasins de Québec, Inc. (CCCL).

(*) Appointed by the Minister of Labour.
Amendment of the decree. Unanimous award, April 12, 1950. Paul Desrochers.

Classon Knitting Mills Ltd. vs Union des Employés Vêtement Sherbrooke (CCCL).

1. Wages: piecework; 2. Paid holidays; 3. Withholding of union dues, voluntary and irrevocable; 4. Sickness and hospitalization plan; 5. General clause: changes of operations, allotment of jobs, right of the company to manage the factory; 6 . Duration of the agreement. Unanimous award, April 17, 1950. G.D. Laviolette.

Commonwealth Plywood Co. Ltd. vs International Upholsterers' Union of North America, Local 388, (TLC-AFL).

Preliminary draft of agreement. Unanimous award, April 21, 1950. Justice C.E. Guérin.

Taggart Service Ltd. vs Union Générale des Travailleurs de Montréal, Section du Transport par Camion (CGL).

1. Working hours; 2. Provision for time off; 3. Vacations; 4. Wages; 5. Overtime; 6. General working conditions. Unanimous award, April 29, 1950. Justice Irenée Lagarde. (*)

\section{COLLECTIVE AGREEMENTS IN QUEBEC}

Cited below are the first of a series of extracts of a collaborative work done under the auspices of the Research Bureau of the Département des relations industrielles.

It is well known that in the Province of Quebec regulation by collective agreement enjoys a role of particular importance and that its purpose is not only to confirm legal arrangements and to establish a more advantageous system of regulation, but still more to permit a variety in regulation which takes account of particular needs. The negotiation of a collective agreement is carried out in complete freedom, but if a workers' association has been officially recognized by the Labour Relations Board as the negotiating agent, the employer is obliged to negotiate with it in good faith, without, however, being bound to sign an agreement.

Agreements signed by a non-incorporated labour union are valid before the Labour Relations Board, but up to the present moment only the agreements concluded with incorporated unions are accorded a juridical recognition. The opinion of the jurists is divided as to the juridical value of a collective agreement signed by an unincorporated union. In the three following tables, no distinction is made between the two. The tabulation is, nevertheless, limited to agreements deposited with the Labour Relations Board, in virtue of articles 19 and 19a of the crganic law in effect in the Province of Quebec, as of December 31, 1948.

In this first part we present three tabulations of agreements signed by the different trade union groups of the province. It will be noted that the number of employers is generally greater than that of the collective agreements, for it often happens that the employer's party in a negotiation is an organization certified by the Labour Relations Board to negotiate in the name of one or more employers. These tables have the advantage of indicating the number of employers and workers subject to decrees under the Collective Agreement Act for certain normative provisions, but generally covered by a collective agreement as to supplementary conditions.

The first table presents a view of the collective agreements deposited with the Labour Relations Board and covers the whole of the manufacturing industry of the province. The second table shows the collective agreements covering all groups except the manufacturing industries. The third and last table is a recapitulation of the first two. 
TABLE I: Collective work agreements deposited with the Labour Relations Board of the Province of Quebec for MANUFACTURING INDUSTRIES, CLASSIFIED ACCORDING TO UNION AFFILIATION, NUMBER OF UNITS NEGOCIATING, NUMBER OF EMPLOYERS AND WORKMEN CONSIDERED, IN EFFECT AS OF DECEMBER, 31, 1948.

\begin{tabular}{|c|c|c|c|c|c|c|c|}
\hline \multirow{2}{*}{$\begin{array}{c}\text { Union } \\
\text { affiliation }\end{array}$} & \multirow{2}{*}{$\begin{array}{c}\text { Number } \\
\text { of units } \\
\text { negociating }\end{array}$} & \multicolumn{3}{|c|}{ NUMBER OF EMPLOYERS } & \multicolumn{3}{|c|}{ NUMBER OF EMPLOYEES } \\
\hline & & $\begin{array}{c}\text { Not } \\
\text { subject } \\
\text { to decree }\end{array}$ & $\begin{array}{l}\text { Subject } \\
\text { to decree }\end{array}$ & Total & $\begin{array}{c}\text { Not } \\
\text { subject } \\
\text { to decree }\end{array}$ & $\begin{array}{l}\text { Subject } \\
\text { to decree }\end{array}$ & Total \\
\hline CCCL & 278 & 167 & 202 & 369 & 31,327 & 15,923 & 47,250 \\
\hline CGL-CIO & 115 & 86 & 41 & 127 & 10,679 & 2,135 & 12,814 \\
\hline TLC-AFL & 209 & 135 & 176 & 311 & 38,400 & 12,094 & 50,494 \\
\hline INDEP. & 100 & 87 & 48 & 135 & 21,630 & 5,272 & 26,902 \\
\hline TOTALS & 702 & 475 & 467 & 942 & 102,036 & 35,424 & 137,460 \\
\hline
\end{tabular}

TABLE II: Collective work agreements deposited with the Labour Relations Board of the Province of Quebec, FOR ALL GROUPS EXCEPT MANUFACTURING INDUSTRIES, CLASSIFIED ACCORDING TO UNION AFFILIATION, NUMBER OF UNITS NEgOtIATING, NUMBER OF EMPLOYERS AND WORKMEN CONSIDERED, IN EFFECT AS OF DECEMBER 31 , 1948.

\begin{tabular}{|c|c|c|c|c|c|c|c|}
\hline \multirow{2}{*}{$\begin{array}{c}\text { Union } \\
\text { affiliation }\end{array}$} & \multirow{2}{*}{$\begin{array}{c}\text { Number } \\
\text { of units } \\
\text { negociating }\end{array}$} & \multicolumn{3}{|c|}{ NUMBER OF EMPLOYERS } & \multicolumn{3}{|c|}{ NUMBER OF EMPLOYEES } \\
\hline & & $\begin{array}{c}\text { Not } \\
\text { subject } \\
\text { to decree }\end{array}$ & $\begin{array}{l}\text { Subject } \\
\text { to decree }\end{array}$ & Total & $\begin{array}{c}\text { Not } \\
\text { subject } \\
\text { to decree }\end{array}$ & $\begin{array}{l}\text { Subject } \\
\text { to } \text { decree }\end{array}$ & Total \\
\hline CCCL & 297 & 388 & 1,318 & 1,706 & 7,121 & 26,003 & 8,743 \\
\hline CGL-CIO & 35 & 39 & 2 & 41 & 11,533 & 1,543 & 4,168 \\
\hline TLC-AFL & 75 & 43 & 38 & 81 & 3,218 & 950 & 13,076 \\
\hline INDEP. & 76 & 73 & 29 & 102 & 8,369 & 374 & 33,124 \\
\hline TOTALS & 483 & 543 & 1,387 & 1,930 & 30,241 & 28,870 & 59,111 \\
\hline
\end{tabular}

TABLE III: Collective wORk AGReEMents Deposited With the Labour Relations Board of the Province of QUEBEC, FOR ALL ESTABLISHMENTS, CLASSIFIED ACCORDING TO UNION AFFILIATION, NUMBER OF NEGOTIATING UNITS, NUMBER OF EMPLOYERS AND WORKERS CONSIDERED, IN EFFECT AS OF DECEMBER 31, 1948.

\begin{tabular}{|c|c|c|c|c|c|c|c|}
\hline \multirow{2}{*}{$\begin{array}{c}\text { Union } \\
\text { affiliation }\end{array}$} & \multirow{2}{*}{$\begin{array}{c}\text { Number } \\
\text { of units } \\
\text { negociating }\end{array}$} & \multicolumn{3}{|c|}{ NUMBER OF EMPLOYERS } & \multicolumn{3}{|c|}{ NUMBER OF EMPLOYEES } \\
\hline & & $\begin{array}{c}\text { Not } \\
\text { subject } \\
\text { to decree }\end{array}$ & $\begin{array}{l}\text { Subject } \\
\text { to decree }\end{array}$ & Total & $\begin{array}{c}\text { Not } \\
\text { subject } \\
\text { to decree }\end{array}$ & $\begin{array}{l}\text { Subject } \\
\text { to decree }\end{array}$ & Total \\
\hline CCCL & 575 & 555 & 1,520 & 2,075 & 38,448 & 41,926 & 80,374 \\
\hline CGL-CIO & 150 & 125 & 43 & 168 & 22,212 & 3,678 & 25,890 \\
\hline TLC-AFL & 284 & 178 & 214 & 392 & 41,618 & 13,044 & 54,662 \\
\hline INDEP. & 176 & 160 & 77 & 237 & 29,999 & 5,646 & 35,645 \\
\hline TOTALS & 1,185 & 1,018 & 1,854 & 2,872 & 132,277 & 64,294 & 196,571 \\
\hline
\end{tabular}

